\title{
ANÁLISIS CRÍTICO DE LA JURISPRUDENCIA DEL TRIBUNAL CONSTITUCIONAL SOBRE EL DERECHO A LA TUTELA JUDICIAL
}

\author{
CRITICAL ANALYSIS OF THE CONSTITUTIONAL COURT \\ JURISPRUDENCE REGARDING THE RIGHT OF JUDICIAL TUTELAGE
}

\begin{abstract}
ANDRÉS BORDALÍ SALAMANCA*
RESUMEN: El presente trabajo realiza un análisis crítico de la jurisprudencia del Tribunal Constitucional chileno sobre el reconocimiento y configuración del derecho fundamental a la tutela judicial en el derecho constitucional chileno. Asimismo, el trabajo comprende las relaciones de este derecho fundamental con el debido proceso y las demás garantías procesales de nuestro orden constitucional. Finaliza con un estudio sobre el objeto del derecho analizado y sus contenidos.
\end{abstract}

Palabras clave: derecho a la tutela judicial, debido proceso, acceso a la justicia, acción procesal, jurisdicción, proceso, acción penal, Tribunal Constitucional chileno, jurisprudencia constitucional, derechos fundamentales

ABSTRACT:This paper examines critically the way the caselaw of Chile's Constitutional Court addresses the basic right to have access to a court (judicial tutelage). Additionally, this article reviews the relation between this basic right to judicial tutelage and the general right to Due Process and other procedural guarantees.

Key words: right of judicial tutelage, fair trial access to justice, judicial action, judicial procedure, criminal action, Chilean Constitutional Court, constitutional jurisprudence, fundamental rights.

\section{INTRODUCCIÓN}

Hace diez años publiqué un trabajo en que intentaba configurar en el orden constitucional chileno un derecho a la tutela judicial o derecho fundamental de acción ${ }^{1}$. Era un intento de configuración, no exento de dificultades, tomando en consideración que existían dos importantes escollos que sortear. En primer lugar, no había -y sigue no habiendo- ninguna disposición constitucional que de manera clara reconociera un derecho de este tipo y, en segundo lugar, existía una escasa labor interpretativa por parte de nuestra doctrina y jurisprudencia constitucional sobre este derecho.

\footnotetext{
* Abogado, Licenciado en Ciencias Jurídicas y Sociales por la Universidad de Chile, Doctor en Derecho por la Universidad de Valladolid, España, Profesor de Derecho Procesal en la Universidad Austral de Chile, casilla 567, Valdivia, Chile. Correo electrónico: abordali@uach.cl.

Este trabajo forma parte y es financiado por el proyecto de investigación Fondecyt No 1100362 sobre "La acción penal", del que el autor es su investigador responsable.
} 
Antes del año 2000, los fallos más relevantes del Tribunal Constitucional que se referían a esta materia correspondieron a aquellos en que en voto de minoría del abogado integrante don Eduardo Soto Kloss, se argumentaba contra la institución del solve et repete que, a su juicio, afectaba el derecho de toda persona a recurrir a la justicia en demanda de sus derechos ${ }^{2}$. Luego se fueron sumando algunos fallos de mayoría que paulatinamente fueron reconociendo y configurando este derecho ${ }^{3}$.

Pasados diez años de ese trabajo, la jurisprudencia del Tribunal Constitucional ha cambiado radicalmente. Por una parte, existen varios fallos que en voto de mayoría se refieren a un derecho fundamental de acción o tutela judicial y, de otra, esos mismos fallos han declarado en varias oportunidades inaplicables preceptos legales e incluso han sido declarados inconstitucionales, siendo expulsados del ordenamiento jurídico, por afectar este derecho fundamental.

Sin embargo, pese a que hoy en día existe un número considerable de fallos que se han pronunciado sobre este derecho, esa jurisprudencia ha sido bastante errática para referirse al mismo. Muestra de ello es que algunas veces se habla del derecho de acceder al órgano jurisdiccional ${ }^{4}$, mientras que en otras ocasiones el Tribunal Constitucional expresa que este derecho de acudir a la justicia es llamado también derecho a la acción o derecho a la tutela judicial ${ }^{5}$. Otras veces se habla de él como derecho fundamental al proceso $^{6}$. Tenemos entonces derecho de acceso al órgano jurisdiccional; derecho a la acción; derecho a la tutela judicial ${ }^{7}$ y derecho al proceso. Cuatro maneras diversas de referirse a un mismo derecho.

Pero las dificultades en la intelección jurisprudencial de este derecho no solo apuntan a un problema de tipo conceptual, sino también a su relación con los demás derechos fundamentales de orden procesal. En ocasiones se diferencia claramente entre un derecho de acceso a los tribunales y un derecho al debido proceso, aunque ambos pertenecientes a un más global derecho a la igual protección de la ley en el ejercicio de los derechos ${ }^{8}$.

\footnotetext{
1 Vid. BORDALÍ (2000).

2 Vid. Sentencia del Tribunal Constitucional de fecha 28 de febrero de 1994, rol No 185, recaída en el control preventivo del proyecto de Ley de Bases del Medio Ambiente y sentencia de fecha 22 de octubre de 1996, rol No 248, recaída en el control preventivo del proyecto de Ley que moderniza el Servicio Nacional de Aduanas.

3 Vid. sentencia del Tribunal Constitucional de fecha 27 de mayo de 1997, rol No 287, recaída en el control preventivo del proyecto de ley que modificaba la Ley No 18.140 sobre Superintendencia de Electricidad y Combustibles y el DFL No 1, de 1982, de Minería, Ley General de Servicios Eléctricos. El voto de mayoría, sin declarar inconstitucional ninguna disposición legal, sí se refería a una idea de acceso a la justicia de las personas como derecho constitucional.

4 Vid. Sentencias del Tribunal Constitucional de fecha 17 de noviembre de 2006, rol No 546, y de fecha 3 de enero de 2008, rol No 792.

5 Vid. Sentencia del Tribunal Constitucional de fecha $1^{\circ}$ de julio de 2008, rol No 946.

6 Vid. Sentencia del Tribunal Constitucional de fecha 28 de enero de 2010, rol No 1535.

7 En ocasiones se le agrega además el calificativo de efectiva (derecho a la tutela judicial efectiva, como en el derecho constitucional español, en su artículo 24.1).

${ }^{8}$ Vid. Sentencia del Tribunal Constitucional de fecha 22 de octubre de 1996, rol No 248 (voto de minoría del abogado integrante Eduardo Soto Kloss).
} 
Otras veces se expresa que el derecho de acción o a la tutela judicial es un presupuesto básico de las garantías de la igual protección en el ejercicio de los derechos y del debido proceso 9 , por lo que el derecho a la igual protección en el ejercicio de los derechos ya no es un metaderecho que comprende al debido proceso, sino que se trata de dos derechos fundamentales diferentes, dos derechos que operan como dos grandes contenedores de otros más, de los que el derecho de acceso a los tribunales de justicia sería presupuesto. En un sentido similar, se dice que el derecho de acceso a la justicia forma parte del derecho a la igual protección de la ley en el ejercicio de los derechos y del derecho a un procedimiento racional y justo, ${ }^{10}$ por lo que se podría concluir que existirían dos metaderechos de carácter procesal en nuestro orden constitucional: un derecho a la igual protección de la ley en el ejercicio de los derechos y un derecho al debido proceso. El derecho de acceso a la justicia forma parte de ellos dos.

En otras sentencias se dice que el derecho de acceso a la justicia es uno de los mecanismos que deben contemplar las reglas procesales para garantizar un justo y racional procedimiento y que constituye un supuesto de la protección de la ley en el ejercicio de los derechos ${ }^{11}$.

En otros casos se dice que el derecho a la tutela judicial efectiva, que estaría reconocido en el inciso primero del numeral tercero del artículo 19 de la Constitución (en adelante CPR), comprende entre otros aspectos el libre acceso a la jurisdicción y el derecho al debido proceso ${ }^{12}$. En este sentido, existiría un metaderecho en nuestro orden constitucional, que es el derecho a la tutela judicial efectiva, del cual el derecho de acción y el debido proceso formarían parte.

Sin embargo, en un fallo más reciente se dice que el derecho de acción y el derecho a la tutela judicial efectiva son elementos propios de las garantías de un procedimiento racional y justo ${ }^{13}$, por lo que la idea de metaderecho estaría referida al debido proceso.

Pero todavía hay más problemas en la jurisprudencia del Tribunal Constitucional. ¿Cuál es la funcionalidad de este derecho? ¿Se reconoce este derecho simplemente para que las personas puedan acceder a los tribunales de justicia, pidan lo que pidan a estos, o bien se trata de un derecho que lo que busca es que las personas puedan solicitar tutela a los tribunales de justicia para los derechos e intereses que ellos reclamen como propios? Hay un fallo del Tribunal Constitucional que señala que el derecho a la tutela judicial tiene esas dos dimensiones ${ }^{14}$. Esto tiene importancia, pues si se desvincula el derecho a la tutela judicial de la protección de derechos e intereses que se reclaman como propios por quienes demandan justicia, el derecho pasa a tener una dimensión abstracta de variada proyección, que podría implicar que las personas puedan iniciar procesos en los que no invoquen ningún derecho o interés comprometido.

\footnotetext{
9 Vid. Sentencia del Tribunal Constitucional de fecha 1 de julio de 2008, rol No 946.

10 Vid. Sentencia del Tribunal Constitucional de fecha 25 de mayo de 2009, rol No 1345.

11 Vid. ibid.

12 Vid. Sentencia del Tribunal Constitucional de fecha 28 de enero de 2010, rol 1535.

13 Vid. Sentencia del Tribunal Constitucional de fecha 22 de junio de 2010, rol 1373.

14 Vid. Sentencia del Tribunal Constitucional de fecha 28 de enero de 2010, rol 1535.
} 
Las hipótesis que intentaré defender en el desarrollo del trabajo apuntan, en primer lugar, a que el derecho a la tutela judicial, que también puede entenderse como derecho de acción o como derecho de acceso a los tribunales o derecho al proceso, debe entenderse reconocido en el artículo 19 No 3 inciso $1^{\circ}$ CPR. Además, sostendré que se trata de un derecho fundamental que no forma parte del derecho al debido proceso, ni él contiene otros derechos fundamentales reconocidos en otras disposiciones de la Constitución. Finalmente, intentaré demostrar que no se trata de un derecho abstracto que asegura siempre y en todo lugar un derecho al proceso judicial, sino que es un derecho que garantiza el acceso a un proceso para pedir tutela de derechos e intereses que se reclaman como propios. Sus contenidos básicos apuntan al derecho a deducir pretensiones ante un tribunal de justicia, a obtener una respuesta de ese tribunal a esa pretensión, si se cumple con los presupuestos procesales y demás requisitos legales, y a una realización efectiva de la decisión judicial en caso que acoja la pretensión deducida. Puede entenderse también que se tiene derecho a recurrir la sentencia en caso que no sea favorable. Para estos últimos aspectos, recurriré a la doctrina y jurisprudencia que al respecto se ha consolidado en el derecho español e italiano.

De todas estas consideraciones quiero hacerme cargo en el presente trabajo, comenzando (I) por tomar una posición en orden a cómo denominar al derecho que se refiere a pedir tutela de los tribunales de justicia, para luego (II) analizar los tipos de derechos que reconoce el artículo 19 No 3 de la Constitución y sus relaciones recíprocas, para continuar (III) con una consideración del objeto del derecho a pedir tutela judicial, siguiendo (IV) con una definición de los contenidos básicos del derecho, finalizando (V) con algunas conclusiones.

\section{EL DERECHO A PEDIR TUTELA DE LOS TRIBUNALES DE JUSTICIA. ¿DERECHO A LA TUTELA JUDICIAL, DERECHO A LA ACCIÓN, DERECHO DE ACCESO AL ÓRGANO JURISDICCIONAL O DERECHO AL PROCESO?}

El derecho a la tutela judicial también puede entenderse como derecho de acción o como derecho de acceso a los tribunales o derecho al proceso.

Sin embargo, existen razones para que hoy en día nos podamos referir a este derecho preferentemente como derecho a la tutela judicial antes que derecho de o a la acción ${ }^{15}$. En primer lugar, existen disposiciones constitucionales en el derecho comparado que se refieren en tales términos a este derecho fundamental que, en principio, garantiza a todas las personas el derecho de acceso a la justicia. Así ocurre con el artículo 24.1 de la Constitución española, precepto que ha generado una profusa literatura y jurisprudencia al respecto y que ha influenciado a todos los sistemas jurídicos iberoamericanos.

Lo mismo sucede con la Constitución italiana, que si bien en su artículo 24 inc. $1^{\circ}$ utiliza la expresión agire en juicio, que podemos entenderlo como actuar u obrar,

15 Uno de los primeros trabajos de la dogmática procesal chilena que comprendía a la acción como un derecho constitucional dirigido hacia el Estado es el de AvSOlOMOVICH, LÜHRS y NOGUERA (1965), p. 26. 
dicho actuar, señala el referido precepto, está destinado a pedir tutela para derechos e intereses legítimos propios de quien pide la tutela.

En segundo lugar, es preferible referirse a la tutela judicial porque evita referirse a un concepto (acción) que en la dogmática procesal chilena y especialmente en la comparada, es abiertamente problemático, no habiendo al día de hoy claridad sobre en qué consiste ni los contenidos que tendría. No parece conveniente trasladar al Derecho Constitucional una categoría propia del Derecho Procesal, muy compleja y criticada ${ }^{16}$, al menos como esta rama del derecho tradicionalmente la ha entendido ${ }^{17}$.

Asimismo, el derecho que garantiza la Constitución, para que constituya una verdadera garantía de las personas ante la prohibición de la autotutela y correspondiente asunción en términos monopólicos por parte del Estado de la tutela de los derechos e intereses, con posibilidad de uso legítimo de de la coacción, no puede consistir en un mero derecho de acceso a los tribunales, sino que se requiere, como veremos, algo más que eso. Desde luego necesita asegurarse, al que ha concurrido al tribunal, de una respuesta por parte de este y si es positiva respecto de la pretensión deducida, de específicos instrumentos que permitan un cumplimiento efectivo de lo dispuesto por el tribunal.

Y con la idea de un mero derecho de acceso al proceso, tampoco se pone la debida atención a que los individuos necesitan del Estado de una organización judicial y procedimental que permita, en los casos que corresponda, de una actividad por parte de los tribunales de justicia que otorgue una tutela o protección efectiva de los derechos o intereses para los que ha pedido amparo quien concurrió ante ellos. En realidad, lo que las personas buscan no es que puedan acceder al proceso, sino un concreto amparo para sus derechos e intereses.

En este orden de cosas, debe tenerse presente que no puede existir un proceso puramente abstracto que exista por sí y para sí mismo, sino que el proceso es instrumento para un fin ulterior que es dar protección a los derechos o intereses de quien concurre ante el órgano jurisdiccional ${ }^{18}$. Evidentemente el ejercicio del derecho a la tutela judicial se concreta fundamentalmente en el poder valerse del instrumento técnico-jurídico a través del cual se forma el acto jurisdiccional erogador de la solicitud de tutela, como lo es el proceso $^{19}$, pero se necesita algo más que eso.

Por todo ello, al derecho del cual hablaré en estas páginas conviene llamarlo derecho a la tutela judicial. No le llamaré tutela judicial con el adjetivo de efectiva, para no utilizar una denominación que es propia de la Constitución española y que más de alguna duda interpretativa ha arrojado para sus tribunales y doctrina. No es apropiado importar gratuitamente esos problemas del Derecho Constitucional español a nuestro derecho.

\footnotetext{
${ }^{16}$ Algún autor, consciente de lo mucho que se ha escrito desde mediados del siglo XIX sobre el significado de la acción, y de los pocos resultados útiles que para el desarrollo efectivo del Derecho Procesal han dado esas discusiones, ha llamado a organizarle unos solemnes funerales al concepto y concentrar los esfuerzos de los procesalistas en otras direcciones. Vid. AlCALÁ - ZAmora y CASTILlo (1992), p. 323.

17 Vid. Comoglio (1970), p. 136.

18 Vid. PROTO PISANI (1978), passim;

19 Vid. ANDOlina y Vignera (1997), p. 72.
} 
El derecho a la tutela judicial debe entenderse reconocido en el artículo 19 No 3 inciso $1^{\circ} \mathrm{CPR}$. De este modo, la primera aclaración que creo necesario realizar es distinguir con meridiana claridad los tipos de derechos procesales que regula el artículo 19 No 3 CPR. Al respecto sostendré que este precepto reconoce:

a) El derecho a la tutela judicial (art. 19 No 3 inc. $1^{\circ}$ CPR).

b) El derecho de defensa jurídica (art. 19 No 3 inc. $2^{\circ} \mathrm{CPR}$ ).

c) El derecho de defensa jurídica gratuita (art. 19 No 3 inc. $3^{\circ} \mathrm{CPR}$ ).

d) El derecho a un juez natural (art. 19 No 3 inc. $4^{\circ}$ CPR).

e) El derecho a un debido proceso (art. 19 No 3 inc. $5^{\circ} \mathrm{CPR}$ ).

Los otros tres últimos incisos del artículo 19 No 3 CPR, no reconocen propiamente derechos fundamentales de contenido procesal, sino del orden penal material ${ }^{20}$.

En el trabajo que escribí diez años atrás sobre este tema ${ }^{21}$, sostuve que sin perjuicio de que en la práctica judicial los dos grandes derechos procesales que en general los ordenamientos constitucionales continentales suelen reconocer a los ciudadanos, como lo son el derecho a la tutela judicial y el derecho al debido proceso, operan íntimamente relacionados, desde un punto de vista analítico pueden perfectamente ser considerados en forma separada.

Por otra parte, desde un punto de vista de la interpretación constitucional, aparece más sensato entender que cada inciso del artículo 19 CPR consagra un derecho diferente. No puede entenderse que esos incisos reiteran lo regulado en los otros, como tampoco puede entenderse que algunos de ellos no tengan ninguna utilidad. Por ello, no comparto el criterio asumido por el Tribunal Constitucional ${ }^{22}$ de referirse genéricamente a los derechos constitucionales de contenido procesal reconocidos en el artículo 19 No 3 $\mathrm{CPR}$, sin especificar dentro de los cinco o, si se quiere, seis numerales que reconocen diferentes derechos de contenido procesal. El artículo 19 No 3 inc. $1^{\circ}$ CPR debe reconocer un derecho cuyo contenido no está comprendido en los demás incisos del referido artículo. Ese derecho es a obtener tutela judicial.

Sin embargo, como veremos más adelante, la situación se complejiza al reconocer dentro del artículo 19 No 3 un derecho de amplio espectro, que además tiene la calidad, como se sostiene en ocasiones, de principio constitucional ${ }^{23}$, como suele referirse al debido proceso, o, en Chile, un racional y justo procedimiento.

\footnotetext{
${ }^{20}$ Con la salvedad, que puede ser discutida, de lo dispuesto en el 19 No 3 inciso 6o: "La ley no podrá presumir de derecho la responsabilidad penal", precepto que puede entenderse referido a que en nuestro sistema procesal penal debe regir el derecho a la presunción de inocencia, el que evidentemente tiene una proyección procesal, pues importa entre otras cosas que la carga de la prueba en el juicio penal para acreditar la existencia del delito y la participación que en él ha tenido el imputado recae sobre el órgano acusador.

${ }^{21}$ Cfr. Bordalí (2000), p. 93.

22 Vid. Sentencias del Tribunal Constitucional de fecha 1 de julio de 2008, rol 946; 25 de mayo de 2009, rol 1345; 28 de enero de 2010, rol 1535.

${ }^{23}$ Vid. ZAPATA (2008), p. 568.
} 
El reconocimiento del derecho a la tutela judicial en el artículo 19 No 3 inc. $1^{\circ}$ CPR fue por lo demás objeto de análisis en la Comisión de Estudio de una Nueva Constitución, la que en su sesión No 100 señaló que no valía la pena incluir una cláusula que expresamente reconociera que "toda persona puede ocurrir a los Tribunales para hacer valer sus derechos y dispondrá de recurso efectivo contra actos que los violen", como alguien pensó agregar al texto constitucional, porque ese derecho de acceso a la justicia ya estaba contenido en el inciso $1^{\circ}$ del art. 19 No 3 CPR.

En este sentido, sí parece correcta la posición del Tribunal Constitucional ${ }^{24}$ de centrar el derecho a la tutela judicial al menos dentro del artículo 19 No 3 CPR, y no en el artículo 19 No $14 \mathrm{CPR}$, como a veces se ha intentado por quienes deducen requerimientos ante él. La tesis que ve al derecho a la tutela judicial como una manifestación del derecho constitucional de petición, tiene el apoyo de la autoritas de cierta doctrina procesal, pues en sus días fue propuesta por un gran tratadista, como lo fuera Eduardo Couture $^{25}$. Sin embargo, no puede aceptarse la tesis que la tutela judicial sea el derecho de petición ante los tribunales de justicia, puesto que con el derecho de petición no se asegura una respuesta por parte de la autoridad ni menos una posibilidad de dar ejecutividad a esa respuesta, entre otros aspectos. Como sostiene el Tribunal Constitucional "el ejercicio del derecho de accionar ante tribunales de justicia tiene reglas especiales que rigen la especie" 26 , que son diferentes del derecho de petición.

La jurisprudencia del Tribunal Constitucional ha visto especificaciones de este derecho a la tutela judicial en otras disposiciones constitucionales, como lo son el artículo 38 inc. $2^{\circ} \mathrm{CPR}$ y el 83 inc. $2^{\circ} \mathrm{CPR}$, que expresan, respectivamente, que "cualquier persona que sea lesionada en sus derechos por la Administración del Estado, de sus organismos o de las municipalidades, podrá reclamar ante los tribunales que determine la ley, sin perjuicio de la responsabilidad que pudiere afectar al funcionario que hubiere causado el daño", y que "el ofendido por el delito y las demás personas que determine la ley podrán ejercer igualmente la acción penal”.

Respecto de aquellas situaciones donde la ley dificulta o entorpece que los administrados puedan impugnar ante los tribunales de justicia las decisiones o actos de la Administración, el Tribunal Constitucional ${ }^{27}$ ha señalado que en esos casos pueden resultar afectados dos derechos fundamentales: el derecho de acceso a la justicia o derecho a la tutela judicial, asegurado de una manera general por el art. 19 No 3 CPR, y el derecho a reclamar a la justicia contra los actos de la Administración, consagrado especialmente con relación a los actos administrativos en el artículo 38 de la misma Carta. Da a entender el Tribunal Constitucional que el artículo 38 inc. $2^{\circ}$ CPR es una especificación del derecho a la tutela judicial reconocido en términos generales en el art. 19 No 3 CPR.

Comentando esta jurisprudencia, hay que señalar que ella aparece correcta. Efectivamente el artículo 38 inc. $2^{\circ} \mathrm{CPR}$ parece reconocer un derecho a la tutela judicial

\footnotetext{
${ }^{24}$ Vid. Sentencia del Tribunal Constitucional de fecha 17 de noviembre de 2006, rol No 546

25 Vid. COUTure (1958), passim.

26 Sentencia del Tribunal Constitucional de fecha 17 de noviembre de 2006, rol No 546.

27 Cfr. Sentencia del Tribunal Constitucional de fecha 1 de julio de 2008, rol No 946.
} 
específicamente dispuesto para cuando la agresión a un derecho del justiciable proviene de un acto o actuación de la Administración del Estado.

Sin embargo, también hay que señalar que si existe un derecho a la tutela judicial para dar amparo a los derechos e intereses de las personas (art. 19 No 3 inc. 10 CPR), debe entenderse que ese derecho comprende todas las posibles fuentes de agresión a esos derechos e intereses, sean actos de particulares o de la Administración del Estado. Por ello, podría prescindirse perfectamente del artículo 38 inc. $2^{\circ}$ CPR y entenderse que, igualmente, las personas en Chile tienen reconocido un derecho a solicitar tutela judicial cuando sufren una vulneración de sus derechos e intereses por parte de la Administración del Estado, vía artículo 19 No 3 inc. $1^{\circ}$ CPR.

Esta aseveración toma aún más fuerza si se parte de la idea que en los últimos decenios, en los países de tradición jurídica continental, se ha producido un acercamiento de la justicia administrativa a la justicia civil. Esto se debe al convencimiento en la doctrina contemporánea, y de los poderes legislativos en algunos casos, que el proceso administrativo no puede seguir siendo considerado como un juicio al acto, sino que debe entenderse como un juicio sobre la relación entre Administración y administrado, es decir, sobre los derechos y obligaciones que se generan entre ellos. Por otra parte, hoy ante la justicia administrativa se tutelan derechos subjetivos o bien intereses legítimos, pero no entendiéndose estos como una situación subjetiva tutelada solo por vía refleja o mediatamente ${ }^{28}$, sino como posiciones jurídicas subjetivas directamente reclamables.

De este modo, los mecanismos procesales administrativos y civiles son muy similares, por lo que sería lógico entender que el derecho a la tutela judicial (19 No 3 inc. $1^{\circ}$ CPR) abarca una necesidad de tutela tanto en el campo civil como administrativo, y desde luego otras áreas del derecho como el Derecho Laboral, Comercial, etcétera.

En este sentido, parece más correcto sostener que cuando la ley impide, pone trabas u obstaculiza el acceso a los tribunales de justicia en los casos que la Administración vulnera o afecta un derecho o interés de una persona, se afecta un solo derecho fundamental y no dos como sostiene el Tribunal Constitucional. Ese único derecho fundamental es el derecho a la tutela judicial.

Ahora bien, podrá sostenerse, atendido a la existencia y actual redacción del artículo 38 inc. $2^{\circ} \mathrm{CPR}$, que ese derecho fundamental a la tutela judicial, respecto de actos o actuaciones de la Administración, aparece reconocido en ese precepto. Es innegable la existencia del precepto y una interpretación constitucional que arroje resultados útiles nos obliga a llegar a resultados como el que se ha expresado.

En materia penal, el Tribunal Constitucional ${ }^{29}$ ha reconocido un derecho a la tutela judicial para el ofendido por delito en el artículo 83 inc. $2^{\circ}$ CPR. En este caso, la situación se complejiza aún más, toda vez que no parece evidente, como en los asuntos civiles y administrativos, que en materia penal el ofendido ejerza este derecho a la tutela judicial para pedir amparo a sus derechos subjetivos o intereses legítimos de carácter

28 Vid. DENTI (2004), p. 113.

29 Vid. Entre otras, las Sentencias del Tribunal Constitucional de fecha 19 de agosto de 2008, rol 815; y de 28 de enero de 2010, rol 1535. 
penal. Es discutible que el ofendido tenga algún derecho o interés de carácter penal, toda vez que en esta materia solo parece haber un interés público comprometido.

Ahora bien, como no parece existir en cabeza del ofendido por delito un derecho o interés legítimo por el cual se pide tutela, parece correcto no incluir en el artículo 19 No 3 inc. $1^{\circ} \mathrm{CPR}$ el tema de la acción penal. Por ello, debe ser visto como algo positivo que el constituyente haya regulado el derecho de los ofendidos por delito para participar del enjuiciamiento criminal en otro apartado de la Constitución. Cuestión aparte, que por ahora no discutiré, es si este derecho del ofendido a participar en el enjuiciamiento criminal sea un verdadero derecho a la tutela judicial o bien se trata de un derecho o facultad de otras características.

\section{EL DERECHO A LA TUTELA JUDICIAL Y AL DEBIDO PROCESO. SUS RELACIONES CON LOS DEMÁS DERECHOS DE CONTENIDO PROCESAL QUE RECONOCE EL ARTÍCULO 19 Nº 3 CPR}

Los tipos de derechos que reconoce el artículo 19 No 3 CPR no es asunto pacífico en la jurisprudencia del Tribunal Constitucional ni en la doctrina constitucional nacional. Las interpretaciones del Tribunal Constitucional han señalado que este precepto constitucional reconoce los siguientes derechos fundamentales:

1) Un derecho fundamental a la igual protección de la ley en el ejercicio de los derechos, derecho global que incluye otros derechos como los de acceso a los tribunales y a la efectiva tutela de los derechos; a la defensa; al juez natural, y a un derecho al debido proceso ${ }^{30}$. El Tribunal Constitucional con posterioridad ha señalado que el derecho de acceso a la justicia tiene la cualidad de ser presupuesto necesario de los otros derechos fundamentales de contenido procesal, como lo son el derecho de defensa, el derecho al juez natural y el derecho al debido proceso ${ }^{31}$.

2) Un derecho fundamental a la tutela judicial efectiva, derecho global que incluye entre otros derechos, el de acceso a los tribunales y al debido proceso. Ha señalado al respecto el Tribunal Constitucional “[...] Este derecho [a la tutela judicial efectiva] incluye el libre acceso a la jurisdicción, el derecho a obtener una resolución acerca de la pretensión deducida, el derecho a la ejecución de las resoluciones judiciales, la interdicción de la indefensión y el derecho al debido proceso [...]"32.

3) Un derecho fundamental al debido proceso, derecho global que incluye entre otros derechos el de acción, el derecho a la tutela judicial efectiva, el derecho a la motivación de las sentencias judiciales, etc. El Tribunal Constitucional ha dicho que "[el derecho del justiciable a la motivación de las sentencias judiciales] es inherente al derecho a la acción y, por ende, a la concreción de la tutela judicial efectiva; elementos propios de las garantías de un procedimiento racional y justo [...]"33.

\footnotetext{
30 Vid. Sentencia del Tribunal Constitucional de fecha 22 de octubre de 1996, rol No 248 (voto de minoría del abogado integrante Eduardo Soto Kloss).

31 Vid. Sentencia del Tribunal Constitucional de fecha 17 de noviembre de 2006, rol No 546.

32 Vid. Sentencia del Tribunal Constitucional de fecha 28 de enero de 2010, rol 1535.

33 Vid. Sentencia del Tribunal Constitucional de fecha 22 de junio de 2010, rol 1373.
} 
4) Dos derechos fundamentales de carácter global: En primer lugar, un derecho a la igual protección de la ley en el ejercicio de los derechos y, en segundo lugar, un derecho al debido proceso. El derecho de acceso a la justicia forma parte de ellos dos. Al respecto, el Tribunal Constitucional ha dicho que "[...] la Constitución sí incluye el derecho de acceso a la justicia entre las garantías de igual protección de la ley en el ejercicio de los derechos, consagradas en el numeral $3^{\circ}$ de su artículo 19. Esta ha sido una doctrina reiterada en varios fallos anteriores de este tribunal. Para tenerla por cierta debe tenerse presente, desde luego, que esa garantía es uno de los mecanismos que deben contemplar las reglas procesales para garantizar un justo y racional procedimiento; porque constituye un supuesto necesario de otras garantías explícitas, como lo son el derecho a la defensa o al juez natural; y porque ella es un supuesto de la protección de la ley en el ejercicio de los derechos, que se consagra en el inciso $1^{\circ}$ de la norma en comento $[\ldots] " 34$.

A mi entender, el único derecho global que reconoce nuestra Constitución es el derecho a un debido proceso. Ello corresponde a una tradición del derecho anglosajón y que nuestro constituyente tuvo presente en la redacción de la Constitución de 1980. Debe tenerse en consideración que la Constitución Política de la República de 1980 no utiliza la expresión debido proceso pero no por un olvido o un explícito deseo de no reconocer esta garantía a las personas, sino para no emplear una denominación que tiene sus orígenes en el derecho anglosajón (due process of law), lo que a juicio de autores como Evans podría haber obligado a los operadores jurídicos nacionales a interpretar la garantía a la luz de lo que la doctrina y jurisprudencia de origen anglosajón han construido al respecto ${ }^{35}$. Por este motivo, el constituyente de 1980 optó por usar la expresión equivalente de "racional y justo procedimiento" (art. 19 No 3 inciso 50 CPR). En esta garantía de nuestro texto constitucional hay que entender el reconocimiento del debido proceso como derecho fundamental de los ciudadanos ${ }^{36}$.

Cuando se hace referencia al debido proceso en nuestra Constitución, nos encontramos con una cláusula de contenido indeterminado que debe ser colmada por el legislador o por los tribunales de justicia. La Comisión de Estudio de una Nueva Constitución (en adelante CENC), en sus sesiones 101 a 103, dejó claro que este derecho fundamental se refería a garantías tales como el emplazamiento de las partes, el examen y objeción de la prueba rendida, la existencia de recursos procesales, la fundamentación de las sentencias, etcétera, enumeración que tiene un mero sentido ejemplar, puesto que el objetivo de la cláusula "racional y justo procedimiento" era el concebir un principio de carácter constitucional que debía ser determinado en cada caso concreto por aquellos órganos competentes para realizar esa labor.

Patricio Zapata define al debido proceso como un "principio constitucional, es decir, un conjunto de ideas de índole jurídico política cuya finalidad es darle operatividad a los valores de la libertad, la igualdad y la seguridad. Tratándose precisamente de

\footnotetext{
34 Vid. Sentencia del Tribunal Constitucional de fecha 25 de mayo de 2009, rol No 1345.

35 Cfr. Evans (2004), p. 148.

36 Vid. Nogueira (2003), p. 170.
} 
un principio y no de una regla fija, el debido proceso admite diferentes modalidades concretas [...] El principio del debido proceso presenta entonces una cierta ductibilidad que no cabe confundir con vaguedad [... $]^{\prime 37}$.

Con el debido proceso o racional y justo procedimiento, estamos frente a un derecho fundamental o principio constitucional que hace las veces de un contenedor de varias garantías procesales para los justiciables, en algunos casos expresamente señaladas por el constituyente en forma separada de la cláusula general, como ocurre con el derecho de defensa, el derecho a un juez natural, entre otras.

Podría entenderse que el debido proceso también comprende a un derecho a la tutela judicial, pero como ya se ha adelantado, a mi juicio conviene considerarlos por separado. La interpretación que propongo realizar del artículo 19 No 3 CPR, es que este contiene varios derechos de contenido procesal y un metaderecho o principio constitucional, que incluye a algunos de estos últimos. En concreto, el debido proceso como principio constitucional incluye todos aquellos derechos que están en la Constitución y en los tratados internacionales sobre derechos humanos suscritos y ratificados por el Estado chileno, a excepción del derecho a la tutela judicial. Puede entenderse también que el debido proceso incluye aquellos derechos y garantías procesales que tanto el legislador como en algunos casos los tribunales de justicia pueden entender que se incluyen en él ${ }^{38}$.

De esta manera, propongo no incluir el derecho a la tutela judicial dentro del debido proceso, sin perjuicio de su íntima relación y convergencia en el ejercicio jurisdiccional. Esa no inclusión de un derecho en el otro se explica porque se trata de derechos que, analíticamente, operan con funciones y en momentos diversos. Mediante el derecho a la tutela judicial los individuos se aseguran el poder de acceso a los tribunales y a obtener de estos una decisión según lo que el derecho prescriba que deba resolverse en ese caso. Este es el contenido más esencial de este derecho. Veremos más adelante que algunos agregan que el derecho fundamental a la tutela judicial comprendería también la motivación de la respuesta jurisdiccional, el derecho a disponer de los recursos procesales y el derecho a la ejecución de esa respuesta jurisdiccional. Lo que se pretende con este derecho a la tutela judicial es que el individuo pueda contar con la potestad jurisdiccional del Estado para obtener tutela para los derechos o intereses que invoca. Este derecho viene a ser la contrapartida del hecho que el Estado asume monopólicamente el uso de la fuerza. Los individuos no pueden tutelar por sí mismos sus derechos e intereses. Solo el Estado puede dar esa tutela y por eso se hace indispensable en el orden constitucional asegurar a las personas, como contenido de un derecho, que podrán acceder a la tutela estatal.

En cambio, con el derecho al debido proceso se asegura una cosa distinta. Se garantiza que la actividad que se desarrollará ante el tribunal de justicia desde que el individuo incoa su actuación o se hace parte en un proceso como demandado o tercero y obtiene una respuesta por parte de este, sea llevada a cabo de una manera tal que

37 ZAPATA (2008), p. 568.

38 Vid. BORDALÍ (2010), pp. 84 y ss. 
permita desde luego exponer todos los aspectos referidos a cuestiones fácticas y jurídicas que desee invocar, a objeto de incidir sobre la decisión del tribunal de justicia. Se pretende así, con el debido proceso, legitimar de un mejor modo la justicia de la decisión judicial. Ya no es simplemente el derecho a obtener una decisión judicial, que se garantiza con la tutela judicial, sino que es el derecho a incidir en el contenido de esa decisión judicial. En virtud del debido proceso el individuo podrá defenderse deduciendo excepciones, alegaciones y defensas; podrá disponer de un letrado; podrá exigir que el juez que lo juzgará sea un juez natural, independiente e imparcial; podrá presentar medios de prueba; etcétera.

De este modo, la interpretación más correcta del artículo 19 No 3 es aquella que sostiene que en dicho precepto constitucional se encuentran contenidos a) el derecho a la tutela judicial (inc. $1^{\mathrm{o}}$ ); b) el derecho de defensa jurídica (inc. $2^{\circ}$ ); c) el derecho de defensa jurídica gratuita (inc. $3^{\circ}$ ); d) el derecho a un juez natural (inc. 4o) y e) el derecho a un debido proceso (inc. $5^{\circ}$ ), este último comprendiendo los derechos de los incisos $2^{\circ}, 3^{\circ}$ y $4^{\circ}$ del referido artículo 19 CPR.

Podrá ser considerado el derecho a la tutela judicial como presupuesto de los demás derechos de contenido procesal, pero conviene darle una entidad autónoma y separada de esos derechos.

El problema que he estado analizando, es decir, de cómo relacionar el derecho a la tutela judicial con el derecho al debido proceso, también se ha producido en el derecho comparado.

En Italia, hasta el año 1999, no existía el reconocimiento en términos expresos de un derecho al debido proceso. La reforma constitucional de ese año 1999 modificó el artículo 111 que en su inciso primero dispone, hoy en día, que "la jurisdicción se actúa mediante el justo proceso regulado por la ley”. Antes del año 1999 el gran derecho constitucional de carácter procesal era el de tutela judicial que reconoce el artículo 24 inc. $1^{\mathrm{o} 39}$.

Este derecho a la tutela judicial incluía el derecho al debido proceso, este último ajeno a la nomenclatura y a la tradición italiana, pues como sabemos tiene orígenes anglosajones. De esta manera, la Constitución italiana consideraba el derecho a la tutela judicial como un complejo teóricamente indeterminado de situaciones procesales activas, dispuesto a garantizar el ejercicio de todos los poderes mediante los cuales las partes están en condiciones de influir en la formación del convencimiento del juez ${ }^{40}$.

Sin embargo, de la tutela judicial como un gran derecho contenedor de otras garantías procesales se fue pasando a un debido proceso que cumple esas función receptora, lo que se explica también por la influencia que poco a poco fue ejerciendo en los estados europeos, como el italiano, el Convenio Europeo de Derechos Humanos, que en su artículo 6 reconoce un "derecho a un proceso equitativo" ${ }^{41}$. Si bien la Corte Constitucional italiana desde hace bastante tiempo venía considerando los contenidos de un

\footnotetext{
39 Vid. ANDOlina y Vignera (1997), p. 64.

40 Vid. Comoglio (1970), p. 152.

41 Vid. MengozZI (2009), p. 46.
} 
proceso justo según la prescripción del referido Convenio ${ }^{42}$, dicho principio y sus reglas no tenían un rol formalmente constitucional que pudiera obligar al legislador ordinario a tenerlo presente en su producción legislativa. Es por ello que a fines de la década de los noventa, se llega a la convicción que era necesario constitucionalizar expresamente algunas de las garantías del justo proceso contenidas en el artículo $6^{\circ}$ de la Convención que no estaban expresamente contenidas en la Constitución italiana de $1947^{43}$.

El justo proceso, desde el año 1999, pasa a ser el gran derecho constitucional de contenido procesal de la Constitución italiana, que comprende no solo las específicas garantías de los diversos incisos de ese artículo 111, sino también las otras garantías de significación procesal contenidas en otras disposiciones de la Constitución italiana. "El principio del "justo proceso" no puede, por tanto, no comprender, por ejemplo, las garantías del derecho de acción y de la efectividad de la tutela de las posiciones jurídicas, ya contenidas en el art. 24 de nuestra Constitución; el derecho al juez natural preconstituido por ley, que prevé el art. 25 Const.; las garantías de independencia del orden judicial; etc." 44 .

En el derecho español la situación no es igual a la italiana, pues no hay ningún precepto constitucional que utilice expresamente la denominación proceso debido, justo o equitativo. El único artículo de la Constitución española donde podría entrar el debido proceso es en el 24. Sin embargo, "se considera de forma mayoritaria que el art. 24.1 hace referencia al derecho a la jurisdicción (derecho de acción), es por tanto un derecho de acceso y no comprendido, por ser cosa distinta, en el proceso debido. Donde encajaría propiamente el proceso debido, en cualesquiera de sus acepciones, es en el art. 24.2 que, y siempre a decir de la doctrina mayoritaria, recoge las garantías que, ya dentro del proceso, aseguran con su cumplimiento el carácter de debido al proceso al que se apliquen" 45 .

Para otros autores españoles, el gran derecho fundamental de contenido procesal en la Constitución española es el derecho a la tutela judicial efectiva, que comprende todos los derechos procesales contenidos en el artículo $24.2 \mathrm{CE}$, y estos a su vez se encuentran comprendidos en el derecho a un proceso con todas las garantías ${ }^{46}$ (debido o justo proceso). Como se ve el asunto no es pacífico en el derecho español.

Tenemos de este modo que en el derecho español se discute si el derecho a la tutela judicial efectiva es el gran derecho que incluye a las demás garantías procesales, incluido el debido proceso. En otros casos se dice que derecho a la tutela judicial efectiva y debido proceso son dos derechos globales que deben ser considerados por separado.

\footnotetext{
42 Para la Corte Constitucional italiana, el metaderecho constitucional de implicancias procesales, parecía ser el debido proceso, antes que la acción o el derecho a la tutela judicial. Esto era así aun antes de la reforma constitucional de 1999. En una sentencia del año 1996, rol No 131, la Corte Constitucional italiana señaló que en la fórmula del justo proceso deben incluirse los principios relativos a los derechos de acción y de defensa en juicio. Vid. GREVI (2000), p. 5.

43 Vid. MENGOZZI (2009), p. 52.

${ }^{44}$ MengozZi (2009), p. 70.

45 ESPARZA (1995), pp. 165 y 166.

46 Vid. Serra (1997), p. 12.
} 
Sin embargo, ese problema del derecho español no debe ser traspasado a nuestro país, como en ocasiones lo hace el Tribunal Constitucional, puesto que nosotros sí tenemos, como desde hace una década en Italia, una cláusula general del debido proceso ("racional y justo proceso").

De este modo, el debido proceso es el gran derecho fundamental de contenido procesal de nuestra Constitución. Para algunos comprenderá en su seno al derecho a la tutela judicial. Para otros, entre los que me incluyo, el debido proceso debe incluir a todos los demás derechos constitucionales de contenido procesal, excluido el derecho a la tutela judicial, que tiene otras finalidades y opera en momentos diferentes.

La existencia en nuestra Constitución de un derecho y principio constitucional de carácter global, como lo es el debido proceso (o justo y racional procedimiento), que incluye a todos los demás derechos de contenido procesal, debe llevarnos a rechazar la idea de considerar a otros derechos o principios con fines globalizadores, como un derecho a la igual protección de la ley en el ejercicio de los derechos o un derecho a la tutela judicial efectiva, como a veces lo señala nuestro Tribunal Constitucional. El único derecho y principio de carácter global en nuestra Constitución es el debido proceso.

\section{OBJETO DEL DERECHO A LA TUTELA JUDICIAL}

Un aspecto sobre el que en nuestra dogmática constitucional no hay todavía claridad, es el objeto que tiene el reconocimiento de este derecho. ¿Qué función u objeto cumple el reconocimiento de este derecho? El Tribunal Constitucional ha señalado en un fallo que el derecho a la tutela judicial "tiene una doble dimensión, por una parte adjetiva, respecto de los otros derechos e intereses, y, por la otra, sustantiva, pues es en sí mismo un derecho fundamental autónomo, que tiene por finalidad que las personas accedan al proceso como medio ordinario de resolución de los conflictos jurídicos, lo que resulta un presupuesto mínimo de todo Estado de Derecho" ${ }^{47}$.

No parece correcto el criterio sustentado por este fallo del Tribunal Constitucional. No es posible distinguir una dimensión adjetiva y sustantiva de este derecho o, como pretende señalar, distinguir entre una dimensión instrumental al servicio de los derechos e intereses de las personas y otra dimensión de derecho fundamental. Puesto en esos términos la disyuntiva es incorrecta. El derecho en cuestión es un derecho fundamental, y como tal, por definición es de carácter sustantivo. Lo que puede cambiar es si este derecho fundamental solo es instrumental a los derechos e intereses de las personas que reclaman tutela del Estado, o bien, si este derecho garantiza siempre el acceso a los tribunales de justicia, se afirme o no la existencia de esos derechos o intereses en cabeza de quien recurre a los tribunales de justicia.

En el derecho italiano se ha entendido mayoritariamente ${ }^{48}$ que el derecho a la tutela judicial (art. 24 inc. $1^{\circ}$ Constitución italiana) no es una facultad meramente abstracta, sino que es un derecho que tiene como finalidad obtener tutela jurisdiccional

\footnotetext{
47 Sentencia del Tribunal Constitucional de fecha 28 de enero de 2010, rol 1535.

48 Vid. Andolina y Vignera (1997), P. 72 y ss; Verde (1988), P. 17; Comoglio (1970), p. 38.
} 
de los derechos subjetivos y de los intereses legítimos ${ }^{49}$. "La acción judicial no se dirige, por consiguiente, de forma genérica, a obtener la solución de una controversia, sino a lograr que se determine la existencia de una situación jurídica" 50 .

Lo mismo sucede en España, donde se ha señalado que el primer contenido de este derecho a la tutela judicial efectiva es la posibilidad de acceder a los órganos jurisdiccionales para que estos se pronuncien sobre la pretensión que formule un afirmado titular de derecho o interés legítimo ${ }^{51}$. Esto quiere decir que el derecho a la tutela judicial no ampara al ciudadano que no invoca derechos subjetivos o intereses legítimos atribuibles a él, como podría ser un ciudadano que invoca un interés público o un mero interés en la legalidad. Se deben invocar por quien pide la tutela a los tribunales derechos e intereses materiales o sustantivos que requieren de tal tutela ${ }^{52}$.

Lo anterior es de toda lógica, pues solo donde hay una situación jurídica subjetiva que es atribuida en la esfera individual del sujeto, se justifica crear un derecho que asegure que esa persona podrá pedir, en caso de ser necesario, tutela al Estado, tomando en consideración que este le ha expropiado a esa persona la posibilidad de autotutelar su derecho o interés.

Lo anterior viene a decir que el derecho a la tutela judicial no debe ser visto como un derecho que independientemente de la existencia de derechos o intereses necesitados de tutela, asegura siempre la apertura de un proceso a quien comparece ante él. Esto debe traducirse en que el derecho en cuestión tendrá utilidad en aquel campo jurídico donde puedan existir esos derechos e intereses, como ocurre en materia civil y comercial, laboral, administrativa y constitucional, al menos, en esta última situación, en los casos en que se pide amparo de derechos fundamentales.

La acción o, ahora, el derecho a la tutela judicial "es un derecho accesorio o instrumental a los derechos materiales previstos por el derecho objetivo (los derechos de crédito, la propiedad y los otros derechos reales, etc.), en el sentido de que existe para procurarles efectividad a través de su declaración y eventual ejecución judicial, si son ignorados o vulnerados" 53 . Ahora bien, no se trata solo de entenderlo aplicable donde existan derechos civiles, sino que también a todo tipo de derechos e intereses, como pueden ser los comerciales, laborales, constitucionales o respecto de la Administración del Estado.

Esto quiere decir que los derechos subjetivos que debe invocar quien reclama la tutela jurisdiccional del Estado, pueden corresponder tanto a derechos subjetivos meramente legales o bien de carácter constitucional o derechos fundamentales. De este modo, no puede compartirse el criterio del Tribunal Constitucional cuando en un fallo ${ }^{54}$ sostiene que el artículo 19 No 3 inciso $1^{\circ} \mathrm{CPR}$ asegura a todas las personas el derecho a ser emplazados y a defenderse de los cargos que le formule la autoridad administrativa,

49 Vid. TARUfFo (2010), p. 132.

50 TARUFFO (2010), p. 133.

${ }^{51}$ Montero Aroca y Flors (2008), p. 65.

52 Vid. De la Oliva (1980), p. 142; Pedraz (2000), p. 30

53 ORMAZÁBAL (2010), p. 118. 
que puedan afectar el legítimo ejercicio de sus derechos fundamentales. El fallo en cuestión restringe indebidamente el derecho a la tutela judicial para solicitar amparo solo a los derechos fundamentales, dejando fuera de consideración los derechos meramente legales.

Ahora bien, el reconocimiento de un derecho a la tutela judicial no significa que solo pueda gozar de él el titular efectivo del derecho o interés reclamado, cuestión, la de la efectiva titularidad, que solo se sabrá con la sentencia definitiva que se dicte al final de la tramitación del proceso. El derecho fundamental en cuestión habrá de reconocerse a quien afirme la titularidad de esos derechos o intereses, o a las personas que, fuera de esos casos, la ley considere como legitimados activos ${ }^{55}$. Ser titular y afirmar ser titular de esos derechos e intereses es algo diferente.

Como se puede apreciar, el campo donde parecería no regir el derecho a la tutela judicial como derecho fundamental, es el penal. En materia penal, se debe asegurar el debido proceso tanto a los ofendidos por el delito como al imputado, pero no se dan las premisas necesarias para asegurar al ofendido por delito un derecho a la tutela judicial. "En el proceso penal no se ejercita ningún derecho subjetivo sino una pura y abstracta facultad de que se ponga en marcha el proceso" 56 . Si se quiere hablar de un derecho a defenderse por parte del ofendido por el delito y por el imputado, en términos de igualdad, lo que según nuestro Tribunal Constitucional aseguraría un derecho a la tutela judicial efectiva ${ }^{57}$, debe hacerse referencia al derecho de defensa, que forma parte de un derecho al debido proceso y no a la tutela judicial.

Si tiene sentido hablar de acción penal, es por razones que escapan del derecho a obtener tutela judicial por parte del Estado para los derechos e intereses de quienes solicitan su socorro. En materia penal, como en todo orden procesal, rige el aforismo ne procedat iudex ex officio, lo que quiere decir que la acción en materia penal no debe ser vista como un derecho del Ministerio Público ni de los ofendidos por delito, sino solo como un mecanismo para asegurar la imparcialidad del juzgador, la que podría afectarse si este último inicia de oficio el procedimiento. El concepto de acción penal, en realidad, aunque previsto en muchas leyes y constituciones, como es el caso de Chile, "representa solo el fruto de una tradición histórica que poco tiene que ver con la realidad del proceso de represión de delitos" 58 .

Por ello es que en el artículo 83 inciso $2^{\circ} \mathrm{CPR}$, habrá de verse cualquier tipo de derecho, pero no el derecho a la tutela judicial como lo estamos definiendo acá.

Tampoco puede decirse que ejerce su derecho a la tutela judicial quien intente reclamar, como actor popular, por la observancia de intereses públicos o un mero interés en la legalidad. Este puede ser el caso de las acciones populares o públicas que se reconocen en el ordenamiento constitucional para la defensa de la supremacía constitucional.

\footnotetext{
${ }^{54}$ Vid. Sentencia del Tribunal Constitucional de fecha 17 de junio de 2003, rol 376.

55 Vid. COMOgLiO (1970), p. 114.

56 OrmazÁbal (2010), p. 119.

57 Vid. Sentencia del Tribunal Constitucional de fecha 28 de enero de 2010, rol 1535.

58 RICCI (2001), p. 143.
} 
Nuestra Constitución reconoce esas acciones populares o públicas para incoar las competencias que el Tribunal Constitucional tiene referidas a declarar la inconstitucionalidad de preceptos legales declarados previamente inaplicables (93 No 7 CPR); para declarar la inconstitucionalidad de las organizaciones y de los movimientos o partidos políticos antidemocráticos (art. 93 No $10 \mathrm{CPR}$ ), y para declarar las inhabilidades constitucionales o legales que afecten a una persona para ser designada Ministro de Estado, permanecer en dicho cargo o desempeñar simultáneamente otras funciones (93 No 13 CPR).

Con las acciones públicas o populares no hay derecho subjetivo ni interés legítimo en juego. Se trata, en este caso, de instrumentos de participación ciudadana para la defensa de interés públicos constitucionales, como la supremacía constitucional, el sistema democrático o el buen gobierno. Quien demanda como actor popular no tiene ningún interés de tipo jurídico atribuible a su esfera subjetiva, sino que invoca un interés que podremos denominar de tipo político o sociológico.

No puede entrar en la lógica del derecho fundamental a la tutela judicial la denominada acción popular o pública, toda vez que no se garantiza a todas las personas, pues una vez que se ha incoado por alguno la petición al órgano jurisdiccional, en este caso al Tribunal Constitucional, ya nadie más podrá reiterar esa petición. Si lo que falla el Tribunal Constitucional no satisface las expectativas de los demás miembros de la comunidad, no es posible que ellos intenten un nuevo requerimiento, pues el fin de participar en la tutela de bienes constitucionales ya se ha agotado.

Ello no obsta que se pueda considerar que, en última instancia, tras un precepto legal que se considera inconstitucional, subyacen derechos e intereses de personas concretas. Pero el proceso constitucional que se incoa para declarar inconstitucional el precepto legal, prescinde de cualquier consideración subjetiva de quien interpone, como actor popular, el requerimiento de inconstitucionalidad. La competencia del art. 93 No 7 CPR es un típico caso de proceso constitucional abstracto u objetivo, que no considera la situación de los derechos e intereses de las personas que incoan la actividad jurisdiccional.

Atendido lo anterior, si el constituyente o el legislador decidieran no atribuir una acción popular o pública para solicitar la declaración de inconstitucionalidad de un precepto legal, y atribuirla en exclusiva, por ejemplo, al Presidente de la República o a las Cámaras o una cuarta parte de ellas, no se viola en ningún momento un derecho a la tutela judicial de las personas. Se trata de una opción de ese constituyente o legislador que no aparece constreñida por ninguna exigencia jurídica fundamental.

Las acciones públicas o populares actúan muy lejos de la lógica y del sentido del derecho fundamental a la tutela judicial. Este derecho debe ser entendido como una contrapartida al hecho que el Estado ha expropiado a las personas la posibilidad de autotutelar sus derechos e intereses. No es legítima y no es posible por tanto la autotutela. Por ello se justifica un derecho para pedir que el Estado, como detentador monopólico de la coacción, tutele tales derechos e intereses. Pero con las acciones populares, que suponen un trasfondo abstracto y objetivo, no hay necesidad de compensar nada a los ciudadanos, pues estos no han sido expropiados de ninguna herramienta que les permita tutelar derechos o intereses a ellos atribuibles. 


\section{CONTENIDOS BÁSICOS DEL DERECHO A LA TUTELA JUDICIAL}

Las sentencias del Tribunal Constitucional chileno que se han referido al derecho a la tutela judicial, además de incorporar elementos que dicen relación, con mayor pertinencia, con un derecho al debido proceso, no han precisado adecuadamente los contenidos que tendría el derecho fundamental.

Así, con un carácter muy general, ha señalado el Tribunal que el artículo 19 No 3 CPR reconoce una serie de derechos como lo son el de acceso a la justicia, el derecho a un juez natural, el derecho a un tribunal independiente e imparcial, el derecho al debido procedimiento, a ser oído (que podría entenderse referido al derecho de defensa), y a que el tribunal resuelva sus pretensiones conforme a Derecho ${ }^{59}$.

En otro caso el Tribunal especifica un poco más el contenido del derecho a la tutela judicial, con el carácter de efectiva como agrega, señalando que comprende el derecho a un "acceso efectivo a la jurisdicción en todos los momentos de su ejercicio, que se manifiesta en la exigibilidad de la apertura y, consecuentemente, de la sustanciación del proceso, además del derecho a participar en los trámites del mismo, en igualdad de condiciones que los demás intervinientes. A la hora de reconocerlo, deben tenerse en cuenta dos elementos que necesariamente son complementarios e interrelacionados: el derecho de acción, de configuración constitucional autoejecutiva, y el derecho a la apertura y posterior sustanciación del proceso, cuyo ejercicio será regulado por la determinación legal de las normas del procedimiento y de la investigación [...]"60.

En un fallo reciente, el Tribunal Constitucional incluye dentro del derecho a la tutela judicial el deber de los tribunales de justicia de motivar sus sentencias, derecho de los justiciables que considera "inherente al derecho a la acción y, por ende, a la concreción de la tutela judicial efectiva; elementos propios de las garantías de un procedimiento racional y justo, cuya ausencia o limitación vulnera la exigencia constitucional $[\ldots] " 61$.

De conformidad con esta jurisprudencia del Tribunal Constitucional, forman parte de un derecho a la tutela judicial, los siguientes derechos:

a) Derecho de acceso a la justicia, derecho que incluye el de solicitar la apertura y sustanciación de un proceso y a participar, en condiciones de igualdad, en los trámites del mismo;

b) Derecho a un tribunal independiente e imparcial;

c) Derecho a un juez natural;

d) Derecho de defensa;

e) Derecho a un debido procedimiento;

f) Derecho a que el Tribunal resuelva sus pretensiones conforme a derecho;

g) Derecho a una sentencia motivada.

\footnotetext{
59 Vid. Sentencia del Tribunal Constitucional de fecha 22 de octubre de 1996, rol No 248.

60 Sentencia del Tribunal Constitucional de fecha 28 de enero de 2010, rol No 1535 .

${ }^{61}$ Sentencia del Tribunal Constitucional de fecha 22 de junio de 2010, rol 1373.
} 
Como se puede observar, hay en este elenco derechos que forman parte de una garantía de acceso a la justicia así como otros del debido proceso. Si consideramos que se trata de derechos diversos y tomando en consideración la doctrina y jurisprudencia de países como España e Italia, donde se ha dado un amplio desarrollo de estas garantías, concluiré que del elenco de derechos que ha dado nuestro Tribunal Constitucional, solo forman parte del derecho a la tutela judicial los siguientes contenidos, los que más adelante procederé a precisar y delimitar:

a) Derecho de acceso a la justicia. Este derecho incluye el solicitar la apertura y la sustanciación del proceso;

b) Derecho a que el tribunal resuelva sus pretensiones conforme a derecho.

Los otros contenidos que ha dado nuestro Tribunal Constitucional en las letras b), c), d), e) y g), corresponden más estrictamente a un debido proceso.

Sin embargo, al elenco que se puede extraer de la jurisprudencia de nuestro Tribunal Constitucional sobre el derecho a la tutela judicial, hay que agregar otros elementos que en el derecho comparado se han considerado que forman parte de él. Entre estos derechos que la doctrina y jurisprudencia española e italiana consideran formar parte de la tutela judicial pueden señalarse:

a) Derecho a la efectividad de las resoluciones judiciales, derecho que incluye contenidos como: i) a la inmodificabilidad de las resoluciones judiciales (o respeto de la cosa juzgada), ii) a disponer de medidas cautelares, y iii) a la ejecución de las resoluciones judiciales.

b) Derecho al recurso legalmente previsto.

Tenemos de este modo que el derecho a la tutela judicial que se reconoce en el artículo 19 No 3 inc. $1^{\circ}$ CPR se compone de los siguientes contenidos:

a) Derecho de acceso a la justicia. Este derecho incluye el solicitar la apertura y la sustanciación del proceso;

b) Derecho a que el tribunal resuelva sus pretensiones conforme a derecho;

c) Derecho a la efectividad de las resoluciones judiciales, derecho que incluye contenidos como: i) a la inmodificabilidad de las resoluciones judiciales (o respeto de la cosa juzgada), ii) a disponer de medidas cautelares, y iii) a la ejecución de las resoluciones judiciales;

d) Derecho al recurso legalmente previsto

El derecho a la tutela judicial es un derecho de tipo prestacional que necesita de configuración legal. Como será el legislador el que en definitiva dé vida al derecho, la jurisprudencia comparada ha puesto especial énfasis en que la ley si bien puede limitar o condicionar el ejercicio del derecho, no puede hacerlo de modo de imponer obstácu- 
los o trabas arbitrarias o caprichos que impidan la tutela garantizada constitucionalmente ${ }^{62}$.

No es por tanto el derecho a la tutela judicial un derecho absoluto ${ }^{63}$ que signifique siempre y en todo lugar la obligación de abrir las puertas de la jurisdicción al que reclama su intervención, tramitar el proceso y dictar sentencia definitiva sobre la pretensión deducida. La ley puede relativizar o condicionar el ejercicio del derecho a la tutela judicial en la medida que pueda predicarse razonabilidad o proporcionalidad en todo ello.

Tomando como premisa general esa posibilidad de limitar o condicionar el ejercicio del derecho fundamental a la tutela judicial, pasaré a revisar someramente cómo debe regular la ley cada uno de los contenidos del derecho a la tutela judicial:

\section{A) DERECHO DE ACCESO A LA JUSTICIA}

El derecho de acceso a la justicia comporta la exigencia de abrir la "puerta" de los tribunales a todo tipo de derecho o interés que pueda requerir de tutela estatal. Si el ordenamiento jurídico reconoce un derecho subjetivo o un interés legítimo ${ }^{64}$, en definitiva cualquier posición jurídica de ventaja atribuible a una persona, "el impedir que esos derechos o interés sean tutelados por el poder judicial, supondría la negación del derecho o del interés mismo. No cabe reconocer un derecho o interés y, luego, negarle el acceso al poder judicial a quien lo afirma" ${ }^{65}$.

Ahora bien, a la persona que afirme la titularidad de un derecho subjetivo o interés legítimo y que requiera amparo jurisdiccional para ellos, la ley puede exigirle que realice trámites previos como agotar las vías administrativas, un intento de mediación o conciliación antes de recurrir a la jurisdicción o inclusive el pago de una proporción de la multa aplicada por la Administración, siempre y cuando todo ello sea razonable y no comporte un impedimento de acceso a la justicia ni retrase injustificadamente la petición de tutela judicial.

La jurisprudencia del Tribunal Constitucional chileno se ha referido en varios fallos al caso en que la ley exige el pago de una proporción de la multa o sanción impuesta por la Administración, es decir, la institución del solve et repete. Esta institu-

\footnotetext{
${ }^{62}$ Vid. Sentencias del Tribunal Constitucional español de fecha 18 de noviembre de 1987, rol No 185 y de fecha 13 de febrero de 2003, rol No 30 .

63 Vid. Montero Aroca y Flors (2008), p. 66.

${ }^{64}$ Nuestro ordenamiento constitucional, a diferencia del español y del italiano, no considera como posiciones jurídicas sustantivas necesitadas de la tutela jurisdiccional, a los intereses legítimos. El artículo 19 № 3 inc. 1० CPR solo habla de derechos. Sin embargo, la doctrina nacional, en algunos casos, señala a los intereses como un tipo particular de posición jurídica subjetiva, diferente, al parecer, del derecho subjetivo. Si ello es así, es decir, si en nuestro ordenamiento jurídico existe la figura de los intereses, como algo diferente del derecho subjetivo, pues entonces el derecho a la tutela judicial debe entenderse que da tutela a ellos. No parece aconsejable una interpretación constitucional que entienda que la tutela de los tribunales solo opera respecto de derechos y no de intereses, solo porque el artículo 19 No 3 inc. $1^{\circ}$ CPR solo nombra a los derechos y no a los intereses. Sobre la existencia de intereses en nuestro Derecho Civil, como una posición diferente del derecho subjetivo, remito a DIEZ (1997), p. 25.

65 Montero Aroca y Flors (2008), p. 65.
} 
ción fue eliminada con carácter general por la Corte Constitucional italiana por sentencia de fecha 31 de mayo de 1961.

En Chile, el Tribunal Constitucional ha tenido diversas opiniones sobre la institución del solve et repete. No se puede decir que este tribunal, a diferencia del caso italiano, la considere contraria en términos generales al derecho a la tutela judicial. Así, en el caso de las multas que la ley permite aplicar a la Superintendencia de Electricidad y Combustibles, respecto de las cuales, para poder reclamarlas, se debe acompañar boleta de consignación a la orden de la Corte de Apelaciones por el 25\% del monto de la referida multa, el Tribunal Constitucional ha señalado que ello no es inconstitucional, por cuanto el precepto legal "no impide el acceso a la justicia de los afectados por la multa, sino solamente lo regula en consideración a la necesidad de asegurar el debido funcionamiento del servicio público que prestan. La exigencia constituye un incentivo efectivo para que las empresas mejoren la coordinación y la seguridad del sistema. En suma, la sanción administrativa y especialmente la consignación respectiva, lejos de tratar de impedir el acceso a la justicia, busca restablecer el orden previamente quebrantado en aras del bien común"66.

Este criterio sustentado por el Tribunal Constitucional cambia cuando se trata de multas que puede aplicar la Dirección del Trabajo. En el proyecto de ley que regulaba el trabajo en régimen de subcontratación, la ley exigía la consignación de la tercera parte de la multa aplicada por el Director del Trabajo. El Tribunal Constitucional señaló que dicha consignación previa era inconstitucional por tener un "carácter indeterminado, carente de un límite, pudiendo, en consecuencia, llegar a cantidades cuya cuantía, en la práctica, entraben más allá de lo razonable el derecho de acceso a la justicia, al restringir tan severamente la posibilidad de reclamar ante un tribunal de la multa impuesta por la autoridad administrativa. Ello resulta contrario a los derechos que asegura el artículo 19 No 3 de la Carta Fundamental, en sus incisos primero y segundo [...]"67.

En el caso de las multas que puede aplicar la Superintendencia de Valores y Seguros, que para que puedan ser reclamadas se exige el pago de un $25 \%$ del monto total de la multa, cuatro ministros del Tribunal Constitucional (Cea, Bertelsen, Vodanovic y Correa $)^{68}$, consideraron que ello "limita de manera severa el derecho de acceder a la justicia del requirente, sin que tan significativa limitación pueda considerarse razonable, pues no guarda proporción alguna con el logro de fines lícitos [...]"69.

Luego el Tribunal Constitucional declaró inaplicable el artículo 171 inciso $1^{\circ}$ del Código Sanitario ${ }^{70}$, llegando, con posterioridad, a declararlo inconstitucional. El referido artículo autorizaba a la autoridad sanitaria a aplicar multas, y para poder reclamar de ellas se las debía pagar de manera íntegra y previamente a recurrir a la jurisdicción. El

\footnotetext{
${ }^{66}$ Sentencia del Tribunal Constitucional de fecha 27 de mayo de 1997, rol No 287.

${ }^{67}$ Sentencia del Tribunal Constitucional de fecha 30 de agosto de 2006, rol No 536.

${ }^{68}$ Como hubo en este caso empate de votos, no se obtuvo la mayoría de votos exigida por el artículo 93

No 6 de la Constitución, por lo que el requerimiento hubo de ser rechazado.

${ }^{69}$ Sentencia del Tribunal Constitucional de fecha 17 de noviembre de 2006, rol No 546.

70 Vid. Sentencias del Tribunal Constitucional de fecha 3 de enero de 2008, rol No 792 y de fecha 22 de julio de 2008, rol No 1046.
} 
Tribunal Constitucional estimó que tal disposición legal "constituye una barrera injustificada y carente de razonabilidad al derecho de acceso a la justicia, que forma parte de la garantía de la igual protección de la ley en el ejercicio de los derechos y del derecho a un procedimiento racional y justo, que consagra la carta Fundamental en el numeral $3^{\circ}$ de su artículo $19[\ldots]^{\prime \prime 1}$.

Nuestro Tribunal Constitucional no se ha pronunciado sobre otras limitaciones que la ley puede establecer al ejercicio del derecho de acceso a la justicia, como la imposición de plazos para deducir la pretensión respectiva, por ejemplo. En el derecho comparado se ha entendido que el establecimiento de plazos para poder deducir la pretensión ante los tribunales de justicia no atenta contra el derecho de acceso a la justicia, siempre que ellos sean razonables ${ }^{72}$.

\section{B) DERECHO A QUE EL TRIBUNAL RESUELVA LAS PRETENSIONES CONFORME A} DERECHO

El derecho a la tutela judicial, al no ser un derecho absoluto, no garantiza siempre y en todo lugar que el tribunal dé inicio y tramite un proceso y dicte, al final, una sentencia definitiva. El legislador está habilitado para declarar inadmisible la demanda, dejando imprejuzgado el fondo, al no cumplirse con determinados presupuestos procesales. Ahora bien, en el derecho español se ha entendido que para que exista perfecta conformidad constitucional en este punto, dichas causales de inadmisión deben interpretarse en el sentido más favorable a la efectividad del derecho de acceso a la justicia (principio pro actione) ${ }^{73}$, con posibilidades concretas de poder subsanar los errores hechos ver por el tribunal, siempre y cuando no tengan su origen "en una actividad contumaz o negligente del interesado y que no dañe la regularidad del procedimiento ni la posición jurídica de la otra parte"74. La ley puede permitir por tanto que el tribunal declare inadmisible la demanda, no pronunciándose sobre la pretensión deducida, si considera, por ejemplo, que es incompetente para conocer de ella, que no se ha constituido patrocinio y poder, que quien demanda carece de legitimación activa o que no se ha cumplido con los requisitos que debe contener la demanda.

Por otra parte, si la demanda judicial es declarada admisible y se inicia la tramitación del proceso, que debe arribar, si no hay voluntad de las partes de ponerle término antes, a la sentencia definitiva, esta no tiene que ser necesariamente favorable al actor. El derecho a la tutela judicial no comprende un derecho a que se acoja la demanda. Lo

\footnotetext{
${ }^{71}$ Sentencia del Tribunal Constitucional de fecha 25 de mayo de 2009, rol No 1345.

72 Vid. Picó I Junoy (1997), p. 46. Andolina y Vignera (1997), p. 80. En el caso italiano, la Corte Constitucional ha realizado un análisis particularizado de si la regulación de un plazo puede o no resultar atentatorio del derecho a la tutela judicial de las personas. De este modo, en sentencia de fecha 5 de julio de 1968, rol 85, dicha Corte declaró inconstitucional un precepto legal laboral que disponía una caducidad del plazo que tenían los herederos del trabajador fallecido por accidente, en cuanto a que a ellos les podían afectar factores de orden psicológico y material que pueden impedirles deducir su pretensión dentro de ese período de tiempo.

73 Vid. MonTERo Aroca y Flors (2008), p. 67.

74 Picó I JunOY (1997), pp. 50 y 51.
} 
único que se garantiza en este caso, es que se dictará una sentencia que fallará el fondo del asunto, de acuerdo a lo que en ese caso prescriba el derecho, y por lo tanto, favorable o no favorable para el actor ${ }^{75}$.

\section{C) DERECHO A LA EFECTIVIDAD DE LAS RESOLUCIONES JUDICIALES}

\section{c.1. derecho a la inmodificabilidad de las resoluciones judiciales (o respeto de la cosa juzgada).}

Se ha entendido en el derecho español que una vez fallado un asunto, adquiriendo la resolución que lo falla la cualidad de firme o ejecutoriada, produciendo por tanto el efecto de cosa juzgada, no puede alterarse lo decidido por ningún poder público, sea tribunal de justicia o de otro tipo. Pero la garantía va más allá, pues obliga a los tribunales a abstenerse de volver a resolver sobre el objeto litigioso ya juzgado previamente por un tribunal de justicia ${ }^{76}$. La única manera como se puede hacer cesar este efecto de la cosa juzgada, es mediante los procedimientos de revisión (recurso de revisión) que haya dispuesto el legislador, como lo es el que regulan los artículos 810 y siguientes de nuestro Código de Procedimiento Civil.

c.2. Derecho a disponer de medidas cautelares. En España, se ha entendido que el derecho a la tutela judicial efectiva incluye el derecho a que el legislador prevea medidas cautelares para que los jueces puedan adoptarlas. Asimismo, se tiene derecho a que el juez resuelva sobre las peticiones de medidas cautelares razonadamente y no de forma arbitraria y carente de fundamento ${ }^{77}$.

El valor que debe ser atribuida a la tutela cautelar, debe entenderse en la necesidad de las partes de un proceso judicial de recibir una tutela judicial que ampare a los derechos e intereses esgrimidos de una manera efectiva y en sus propios términos.

La Corte Constitucional italiana, por sentencia rol No 190 de 1985, ha afirmado que la tutela cautelar constituye un componente esencial del derecho a la tutela judicial, que no puede ser eliminado por el legislador.

Sin embargo, parte de la doctrina procesal italiana señaló, en relación a este fallo de la Corte Constitucional, que lo que prevé el derecho a la tutela judicial, no es la previsión de medidas cautelares, sino de distintas modalidades de tutela flexible, cautelares o no cautelares, que puedan dar una tutela pronta y efectiva según el tipo de derechos e intereses de que se trate ${ }^{78}$.

c.3. Derecho a la ejecución de las resoluciones judiciales. La tutela judicial no se satisface únicamente con una sentencia sobre el fondo, si es que se han cumplido con los

\footnotetext{
75 Vid. ORTElls, Cámara y JUAN (2008), p. 208.

76 Vid. ORMAŹ́BAl (2010), p. 125.

77 Vid. Ortells, Cámara y JuAn (2008), p. 209. Otros autores precisan un poco más la obligación de regular recursos en materia penal, puesto que, expresan, solo se trata de un derecho para el condenado por la sentencia penal y no para todos los intervinientes del proceso penal. Vid. ORMAZÁBAL (2010), p. 124.

78 Vid. TOMMASEO (2008), p. 168.
} 
requisitos y presupuestos procesales exigidos por el legislador, ya que de poco serviría esa resolución si después no pudiera materializarse o hacerse cumplir el mandato que contiene. De este modo, se ha entendido en España que impedir o no dar lugar arbitrariamente a la ejecución de una resolución constituye una infracción al artículo 24.1 de la Constitución española ${ }^{79}$.

\section{d) Derecho al recurso legalmente previsto}

Se ha entendido en el derecho comparado que, salvo en materia penal, el legislador tiene libertad para reconocer recursos procesales en los distintos tipos de procedimientos ${ }^{80}$. Sin embargo, se ha precisado también que si el legislador opta por regular un recurso procesal, constituye un atentado al derecho a la tutela judicial si el tribunal competente lo deniega arbitrariamente ${ }^{81}$.

\section{CONCLUSIONES}

1. El derecho a la tutela judicial no tiene un expreso reconocimiento en nuestra Constitución Política de la República. Sin embargo, la jurisprudencia del Tribunal Constitucional poco a poco ha ido consolidando una doctrina que deja en clara evidencia que el derecho a la tutela judicial, como derecho fundamental de todas las personas, sí tiene cabida en nuestra Constitución, con un carácter general en el artículo 19 No 3 $\mathrm{CPR}$, y con una dimensión específica para asuntos administrativos en el 38 inc. 20 CPR y en el 83 inc. $2^{\circ} \mathrm{CPR}$, para el ofendido por delitos.

2. El derecho a la tutela judicial es comprendido por la jurisprudencia del Tribunal Constitucional como sinónimo de derecho a la acción, derecho de acceso a los tribunales o al órgano jurisdiccional y a veces también como sinónimo de derecho al proceso. Sin embargo, parece ser que la mejor expresión para designar a este derecho fundamental es la de derecho a la tutela judicial.

3. El Tribunal Constitucional chileno tiene una distinta y algo errática comprensión del derecho fundamental a la tutela judicial. En ocasiones, junto con el derecho al debido proceso, el derecho al juez natural, el derecho de defensa, entre otros derechos, lo hace formar parte de un global derecho a la igual protección de la ley en el ejercicio de los derechos de las personas (19 No 3 inc. 10 CPR). En otras ocasiones, ha señalado que el derecho de acceso a los tribunales, junto al debido proceso, forman parte de un global derecho fundamental a la tutela judicial efectiva, parafraseando en esta última parte a la denominación expresa de la Constitución española (art. 24. 1). En otros casos, el Tribunal Constitucional señala que en la Constitución existen dos derechos procesales de carácter global: el derecho a la igual protección de la ley en el ejercicio de los derechos y el derecho al debido proceso. El derecho de acceso a la justicia formaría parte de estos dos derechos generales. Finalmente, en otros casos el Tribunal Constitucional ha

\footnotetext{
79 Vid. ORMAZÁBAL (2010), p. 125.

80 Vid. Ortells, Cámara y JuAn (2008), p. 209.

81 Vid. Ortells, CÁmara y JuAN (2008), p. 209.
} 
señalado que el derecho de acción y el derecho a la tutela judicial efectiva forman parte de un global derecho al debido proceso. A mi juicio, esta es la posición más correcta para nuestro orden constitucional. El único derecho fundamental de carácter global que tenemos es el debido proceso. En lo único que me distanciaré en este punto del Tribunal Constitucional, es que soy de la opinión que el derecho general al debido proceso no incluye dentro de sí al derecho a la tutela judicial. El derecho al debido proceso engloba un conjunto de garantías procesales. Forman parte de él el derecho a un juez independiente e imparcial, el derecho a juez natural, el derecho de defensa, entre otros. Sin embargo, el derecho a la tutela judicial no forma parte del debido proceso, pues tiene un objeto diferente y opera en momentos diferentes al debido proceso, sin perjuicio, obviamente, de tener una íntima relación con este último desde el momento que se ponen en contacto en el ejercicio jurisdiccional. Se trata de una diferenciación conceptual y analítica. Estamos frente a dos derechos fundamentales diferentes que entran en contacto y se relacionan, cada uno en su ámbito, cuando se pone en movimiento la maquinaria judicial. Se puede expresar todo esto diciendo que mediante el derecho a la tutela judicial se permite a todas las personas acceder y proveerse de la actividad jurisdiccional del Estado, mientras que el derecho al debido proceso garantiza a esas mismas personas que la respuesta jurisdiccional estatal será el fruto de una actividad que respeta ciertos requisitos o principios del andar procesal que permiten legitimar de un modo adecuado la justicia de la decisión judicial. Con el debido proceso las personas pueden incidir sobre el contenido de la decisión judicial que debe dar el Estado-jurisdicción.

4. El derecho a la tutela judicial tiene por objeto poner en movimiento el proceso judicial solo para dar tutela a los derechos y, quizá también, a los intereses legítimos, de quienes concurren a los tribunales de justicia pidiendo el auxilio del Estado. No tiene este derecho fundamental por objeto un poder abstracto de acceso a la justicia, desvinculado de concretos derechos e intereses necesitados de tutela. De este modo, la acción popular que ejerce una persona con el puro ánimo de defender la ley o la Constitución no forma parte de este derecho. Asimismo, la participación de los ofendidos por delito, en el procedimiento penal, tampoco puede ser vista bajo la óptica de este derecho fundamental. Los ofendidos por delito tendrán derecho al debido proceso y a participar en el enjuiciamiento criminal, pero no porque tengan un derecho a la tutela judicial.

5. El derecho a la tutela judicial tiene como contenidos mínimos los siguientes: a) Derecho de acceso a la justicia; b) Derecho a que el tribunal resuelva sus pretensiones conforme a derecho; c) Derecho a la efectividad de las resoluciones judiciales, derecho que incluye entre sus contenidos: i) la inmodificabilidad de las resoluciones judiciales (o respeto de la cosa juzgada), ii) disponer de medidas cautelares, y iii) la ejecución de las resoluciones judiciales; y finalmente, d) Derecho al recurso legalmente previsto.

\section{BIBLIOGRAFÍA CITADA}

Alcalá-Zamora y CASTillo, Niceto (1992): Estudios de teoría general e historia del proceso (1945-1972), Tomo I, números 1-11 (México D.F., Universidad Nacional Autónoma de México). 
ANDOLINA, Italo y VignerA, Giuseppe (1997): I fondamenti costituzionale della giustizia civile. Il modello costituzionale del processo civile italiano (Turín, Giappichelli).

Avsolomovich, Alex; LÜHrs, Germán y Noguera, Ernesto (1965): Nociones de derecho procesal (Santiago, Editorial Jurídica de Chile).

BORDALÍ, Andrés (2000): "El derecho fundamental de acción: Un intento de configuración en el orden constitucional chileno", Revista de Derecho y Jurisprudencia, tomo XCVII - No 3.

Bordalí, Andrés (2010): La independencia judicial en el derecho chileno (Santiago, Universidad Austral de Chile - Abeledo Perrot LegalPublishing).

Comoglio, Luigi Paolo (1970): La garanzia costituzionale dell azione ed il processo civile (Padua, Cedam).

Couture, Eduardo (1958): Fundamentos del Derecho Procesal Civil (tercera edición, Buenos Aires, Depalma).

DE la OliVA, Andrés (1980): Sobre el derecho a la tutela jurisdiccional. La persona ante la Administración de Justicia: Derechos básicos (Barcelona, Bosch).

DENTI, Vittorio (2004): La giustizia civile (novena edición, Bolonia, Il Mulino).

DiEZ, José Luis (1997): El daño extracontractual en el derecho chileno (Santiago, Editorial Jurídica de Chile).

ESPARZA, Iñaki (1995): El principio del proceso debido (Barcelona, Bosch).

EvAnS, Enrique (2004): Los derechos constitucionales, tomo II (tercera edición, Santiago, Editorial Jurídica de Chile).

GREVI, Vittorio (2000): Alla ricerca di un processo penale "giusto". Itinerari e prospettive (Milán, Giuffrè).

MengOzZI, Marta (2009): Giusto processo e processo amministrativo (Milán, Giuffrè).

Montero ArocA, Juan y FlorS, José (2008): Amparo constitucional y proceso civil (segunda edición, Valencia, Tirant lo Blanch).

Nogueira, Humberto (2003): "La constitucionalización del proceso: El acceso a la jurisdicción, tutela judicial efectiva o debido proceso", en: FERrADA, Juan Carlos (coordinador), La constitucionalización del derecho chileno (Santiago, Universidad Austral de Chile, Editorial Jurídica de Chile).

ORMAZÁBAL, Guillermo (2010): Introducción al derecho procesal (cuarta edición, Madrid, Marcial Pons).

Ortells, Manuel; Cámara, Juan y JuAn, Ricardo (2008): Derecho procesal. Introducción (Valencia, Ediciones Nomos).

Pedraz, Ernesto (2000): Derecho procesal penal. Tomo I. Principios de derecho procesal penal (Madrid, Colex).

PICÓ I JUNOY, Joan (1997): Las garantías constitucionales del proceso (Barcelona, Bosch).

PROTO PISANI, Andrea (1978): "Note minime sulla c.d. tutela giurisdizionale differenziata”, Diritto e Giurisprudenza, año 93 - serie III, vol. XXXIV.

RICCI, Gian Franco (2001): Principi di diritto processuale generale (Turín, Giappichelli).

Serra, Manuel (1997): Prólogo al libro de Joan Picó I Junoy, Las garantías constitucionales del proceso (Barcelona, Bosch).

TARUfFo, Michele (2010): Simplemente la verdad (Madrid, Marcial Pons). 
TOMMASEO, Ferruccio (2008): "Il fondamento costituzionale della tutela cautelare", CipRIANI, Franco (coordinador), Stato di diritto e garanzie processuali (Nápoles, Edizioni scientifiche italiane).

Verde, Giovanni (1988): Profili del processo civile. Parte generale (segunda edición, Nápoles, Jovene editore).

ZapaTA, Patricio (2008): Justicia Constitucional. Teoría y práctica en el derecho chileno (Santiago, Editorial Jurídica de Chile). 
